表 3 モノマー初濃度とポリマー組成の実験值 および計算值の関係

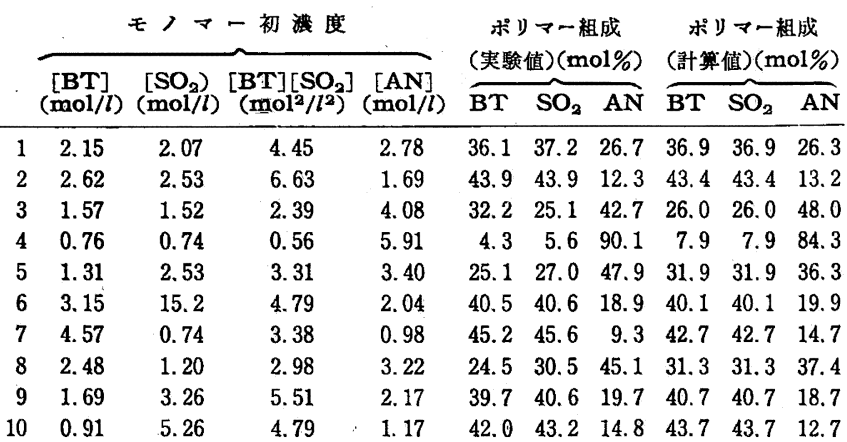

が得られた。（7）式にこの值を代入すると，モノマー組成とポ リマー組成の関係を表わす式として（9）式が得られる。

$\frac{(\mathrm{C})}{(\mathrm{AN})}=\frac{(\mathrm{BT})}{(\mathrm{AN})}=\frac{\left(\mathrm{SO}_{2}\right)}{(\mathrm{AN})}=\frac{[\mathrm{BT}]\left[\mathrm{SO}_{2}\right]}{[\mathrm{AN}]} \cdot \frac{0.8[\mathrm{BT}]\left[\mathrm{SO}_{2}\right]+[\mathrm{AN}]}{[\mathrm{BT}]\left[\mathrm{SO}_{2}\right]+1.0[\mathrm{AN}]}$

この式を用いてモノマー組成からポリマー組成を計算した。表

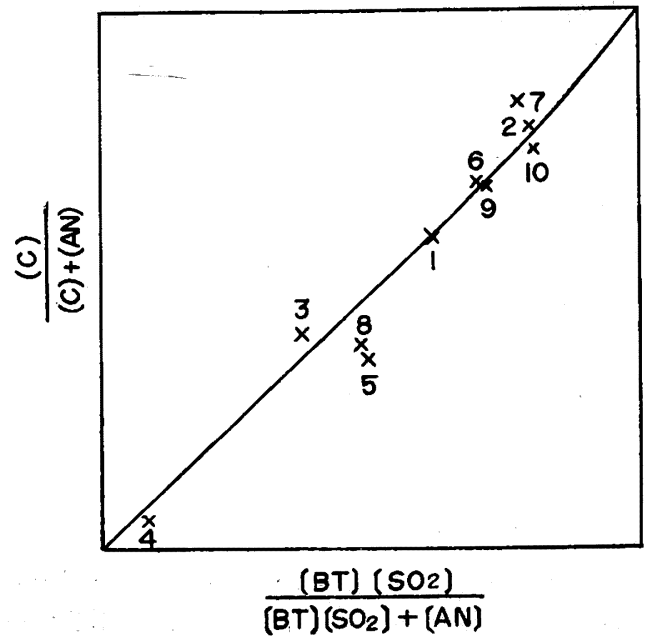

図 2 ポリマー組成計算値と実験値の比較 曲線：計算値 $\mathrm{x}$ ：实驩値 四中の数字は実駼番号を示す

3 および図 2 に実験值と計算值を対比して示す。実験值はかなり よい一致を示し, 以上の取り扱いが妥当であることがわかる。

\title{
液体亜硫酸ージメチルスルホキシド混合溶媒中におけるスチレンおよび アクリロニトリルのラジカル重合反応に及ぼす塩類効果け
}

(昭和 37 年 2 月 17 日 受 理)

\author{
户倉 仁一郎・松 田実・吉 地 宏*
}

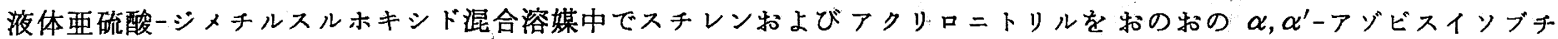
ロニトリルを開始剤としてラジカル重合させ，この系にヨウ化カリウム，塩化リチウム，臭化テトラェチルアンモニウム

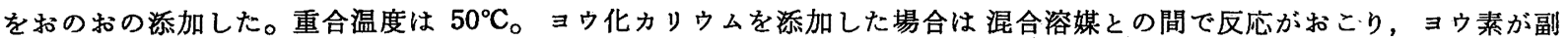
生してこれがラジカルを捕捉すると同時に，不純物ができるために速度を著しく減少させる。塩化りチウムの場合では注 とんど影響を与えなかった。臭化テトラェチルアンモニウムはスチレンに対しては影響がなかったが, アクリロニトリル では速度はその濃度とともに減少する。重合度は速度が低下するものでは同じように減少する。ポリマーの組成は塩類を 添加しても影響なく、スチレンポリスルホンとポリアクリロニトリルをおのおの与える。
\end{abstract}

\section{1 緒 言}

ラジカル重合に扣よぼす溶媒効果や塩類の添加の影響はラジカ ル反応の中のイオン性として興味のあたれるところであって，こ れらは反応の途中でイオン的な因子が強く働いている。ラジカル 重合における極性の問題は共重合反応においてとくによく検討さ れていて，Alfley と Pricel)によって定量化された。 Bamford ら2) はジメチルホルムアミド中のアクリロニトリルのラジカル重 合に塩化りチウムを添加したとき速度と重合度がふえることを見 出したが，これは生長連鎖末端の炭素についているラジカルの極 性が塩を添加することによって变化することを実証したるのであ る。著者らはスチレンおよびアクリロニトリルの液体亜硫酸中の

†本報を「液体亜硫酸中における重合反応（第 11 報）」とす る. 前報は松田, 飯野, 可倉, Makromol. Chem., 52,!98 (1962).

* 東北大学非水溶液化学研究所: 仙台市片平丁.

1) T.Alfrey, C. C. Price, J. Polymer. Sci. 2, 101(1947).

2) C. H. Bamford, A. D. Jenkins, R. Johnston, Proc. Roy. Soc. A 241, 364 (1957). ラジカル重合に打いて液体亜硫酸と相互作用（interaction）をも つ溶媒引をそれぞれ添加して速度と重合度に怙よぼす影響を先き に検討したが，スチレンではがほとんど影響がなく，アリリロニ トリルの場合5)には添加した溶媒の種類によって減少する場合が 認められた。これらの違いはモノマー自身のもつ構造上からくる 極性の差で説明することができる。塩類の添加はもっと大きな笴 与を速度, 重合度, それにポリスルホンの組成に与えることが予 想される。本研究は液体亜硫酸にとけ易い塩を選びジメチルスル ホキシドとの混合溶媒中で重合を行なった。ジメチルスルホキシ ドを加えたのはこれが塩と液体亜硫酸の両方にすぐれた溶媒6,7)

3) L. J. Andrews, R. M. Keefer, J. Am. Chem. Soc. 73, 4169 (1951).

4）戸倉，松田，河原，小川，工化，65，1095 (1962).

5） 戸倉，松田，河原，Sci. Rep. of Res. Inst. Tohoku Univ. A 14, 182 (1962).

6) T.Smedslund, Nord Kemistmötet 7, 199 (1950); Chem. Abst. 48, 6954 (1954).

7) R. L. Burwells. Jr., C. H. Langford, J. Am. Chem. Soc. 81, 3799 (1959). 
であるからで, 添加する塩類の濃度変化を大きくすることが可能 となる。しかし混合溶媒は一方で反応の解析を複雑にした。

\section{2 実験}

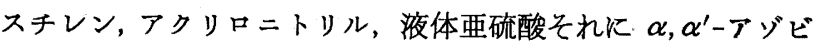
スイソブチロニトリル (AIBN) は常法により精业した ${ }^{8)}$ 。ジメチ ルスルホキシド (DMSO) は，炭酸カリウムで脱水後減圧蒸留し た。bp $120^{\circ} \mathrm{C} / 97 \mathrm{mmHg}$. ヨウ化カリウム, 塩化リチウム, 臭化 テトラエチルアンモニウムは東京化成（株）製の 1 級試薬を乾燥 して用いた。重合速度は重量法ですとめた。重合管の調整は所定 濃度の添加物ージメチルスルホキシド溶液を所定量ピベットで入 れ，その上に濃度既知の AIBN-スチレンもしくはAIBN-アクリ ロニトリル溶液を加え，これを既報の液体亜硫酸滴下装、置 ${ }^{8)}$ にセ ットし窒素で置换し，液体亜硫酸を一定量すつ加えた。重合温度 は $50^{\circ} \mathrm{C}$ 。重合終了後はメタノールに投入し口過して恒量となる まで乾燥した。ポリマーの組成は炭水素と窒素の微量定量分析を 行なって決めた。極限粘度はジメチルホルムアミド中, ウベロー デ型粘度計を使い $25^{\circ} \mathrm{C}$ であとめた。

\section{3 結 果と考 察}

$3 \cdot 1$ 全重合速度 $\left(\boldsymbol{R}_{\mathrm{p}}\right)$

$3 \cdot 1 \cdot 1$ 液体亜硫酸-ジメチルスルホキシト（DMSO）混合溶媒 中における重合

$3 \cdot 1 \cdot 1 \cdot 1$ スチレンの重合 液体亜硫酸初濃度 ([liq. $\left.\mathrm{SO}_{2}\right]$ ) を $7.77 \mathrm{~mol} / l$ (38.46 vol \%), [DMSO]。を $3.25 \mathrm{~mol} / l$ (23.08 vol

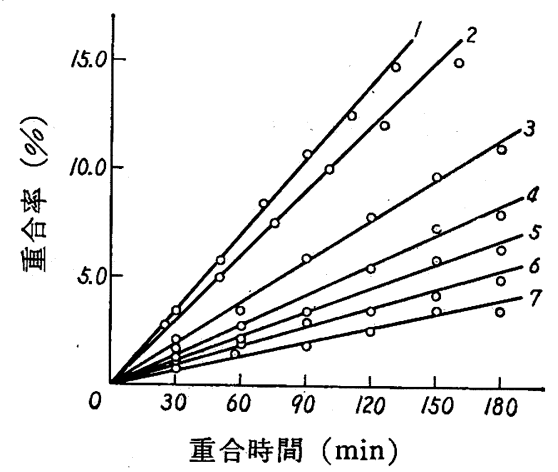

図 1 液体亜硫酸ージメチルスルホキシド中のスチレンの重合

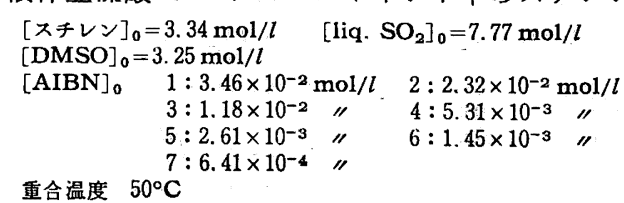

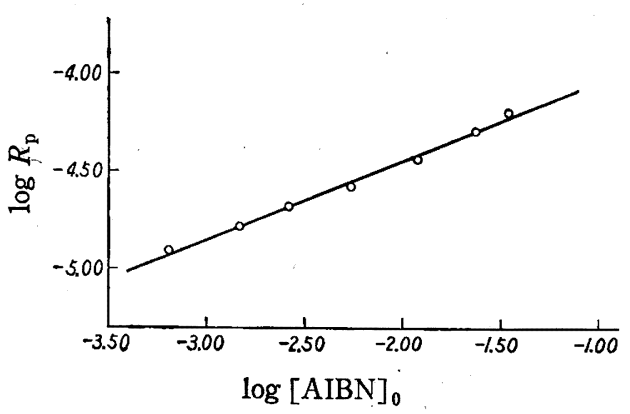

因 2 スチレン重合の場合の全重合速度と 開始剂初濃度の両対数軸プロット

8) 戸倉，松田，工化 64，501 (1961).
\%)，[スチレン]; を $3.34 \mathrm{~mol} / \mathrm{l} \quad(38.46 \mathrm{vol} \%)$ と一定にし, [AIBN] $]_{0}$ を $3.46 \times 10^{-2} \sim 6.41 \times 10^{-4} \mathrm{~mol} / l$ の間で変化させて重 合を行なった。重合率一特間曲線を図 1 K, $R_{\mathrm{p}}$ と $[\mathrm{AIBN}]_{0}$ の両 対数軸プロットを図 2 に示す。これより次式をうる。

$$
R_{\mathrm{p}}=\text { const } \times[\mathrm{AIBN}]_{0}^{0.48}
$$

$3 \cdot 1 \cdot 1 \cdot 2$ アクリロニトリルの重合アクリロニトリル初濃度 を（[アクリロニトリル $\left.]_{0}\right)$ を $5.81 \mathrm{~mol} / l(38.46 \mathrm{vol} \%)$ とした 以外は $3 \cdot 1 \cdot 1 \cdot 1$ と同じ条件で重合を行なった。図 3 , 図 4 の結 果より（2式）がえられる。

$$
R_{\mathrm{p}}=\text { const } \times[\mathrm{AIBN}]_{0}^{0.72}
$$

上式で AIBN に関する次数が液体亜硫酸中の昜合9)にもとめ た 0.87 より小さい值となっているのは DMSO がアクリロニト リルポリマーの良溶媒であるため, 液体亜硫酸との混合系では 0.50 にねり近い值を示したわけで，それだけ 1 分子停止が少な くなっで、る。以上の実験は以下にのべる塩類の効果をみるため の基本となる。

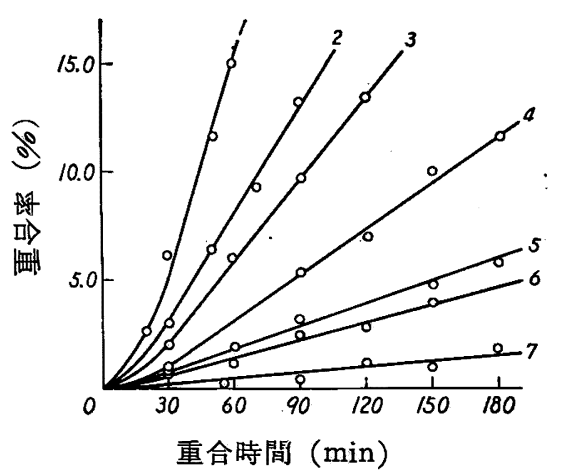

図 3 液体亜硫酸一シメチルスルホキシド中 のアクリロニトリルの重合 [アリリロニトリル $]_{0}=5.81 \mathrm{~mol} / l$ その他の濃庋は図 1 の值と同し

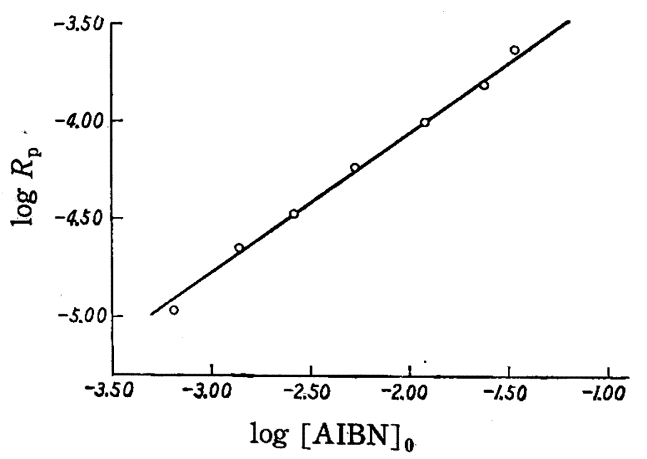

図 4 アクリロニトリル重合の場合の全重合速度 と開始剤初濃度の両対数軸プロット

\section{$3 \cdot 1 \cdot 2$ ヨウ化カリウムを $3 \cdot 1 \cdot 1$ 系に添加した場合}

$3 \cdot 1 \cdot 2 \cdot 1$ スチレンの重合 $[\mathrm{AIBN}]_{0}$ を $3.05 \times 10^{-2} \mathrm{~mol} / l$ と一 定に保ちヨウ化カリウム初濃度（[KI $]_{0}$ ) $2.78 \times 10^{-1} \sim 3.95 \times$ $10^{-4} \mathrm{~mol} / \mathrm{l}$ の間で変化させた以外は $3 \cdot 1 \cdot 1$ と同じ条件下で重合を 行なった。ヨウ化カリウムはあらかじめジメチルスルホキシドに 溶かして括いて一定量重合管に科量した。液体亜硫酸-ジメチル スルホキシド混合溶媒を使ったのは添加物（この場合にはヨウ化 カリウム）の溶解度が液体垔硫酸中では小さいために濃度に制限 を受けるためである。重合率-時間関係を図 5 に示す。この図の特 徴は $[\mathrm{KI}]_{0}$ が大となるにつれて $R_{\mathrm{p}}$ が減少する傾向を示すこと

9）戸倉, 松田, 矢崎, Makromol. Chem. 42, 108 (1960). 


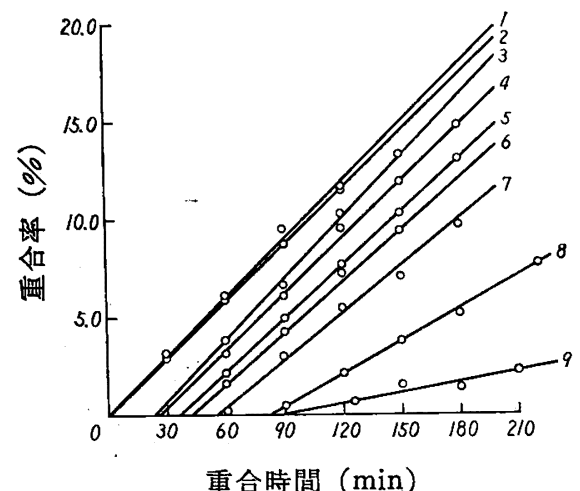

図 5 液体垔硫酸ージメチルスルホキシド中のスチレン の重合にヨウ化カリウムを添加した場合

[KI]。 $\quad 1: 3.95 \times 10^{-1} \mathrm{~mol} / \mathrm{l} \quad 4: 8.78 \times 10^{-3} \mathrm{~mol} / \mathrm{l} \quad 7: 5.56 \times 10^{-2} \mathrm{~mol} / \mathrm{l}$ $2: 8.87 \times 10^{-4} "$ " $5: 3.05 \times 10^{-2} "$ " $8: 1.11 \times 10^{-1} "$ $3: 3.39 \times 10^{-3}$ " $6: 3.21 \times 10^{-2} "$ " $9: 2.78 \times 10^{-1} "$

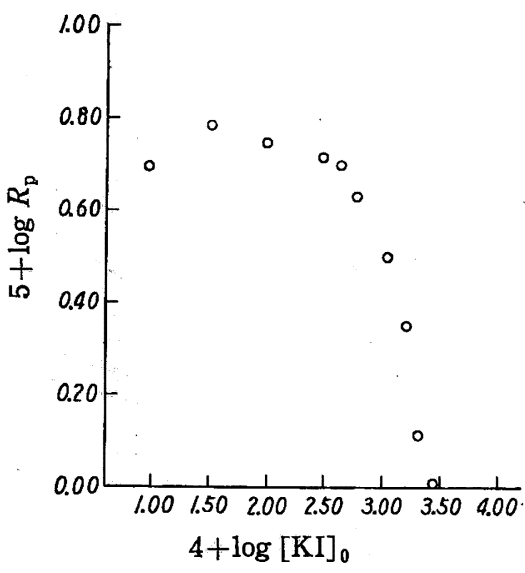

図 6 スチレンの重合にヨウ化カリウムを添加した時に

得られた $R_{\mathrm{p}}$ と $[\mathrm{KI}]_{0}$ の両対数軸プロット

(図 6 K $R_{\mathrm{p}}$ と $[\mathrm{KI}]_{0}$ の両対数軸プロットを示す)，誘導期間は $[\mathrm{KI}]_{0}$ ととあに長くなっていることである。重合管の外観上の特 徴を示すと，反応槽に投入するとすぐに溶液が深赤色を呈するこ とで，この色が消える時間を $[\mathrm{KI}]_{0}$ の異なる括の拈のの重合系 で測ったところ誘導期間と見事に一致する。この色はヨウ素を液 体亜硫酸を溶かしたときの色と全く同じで, 重合管の溶液を極く 少量とってシクロヘキサンで希釈し，紫外吸収スペクトルをとっ だころ，ヨウ素の特性吸収である $500 \mathrm{~m} \mu$ の近くにやや幅の広 い吸収を示しヨウ素ができていることを確認した。外観上のもう 一つの特徴は $[\mathrm{KI}]_{0}$ が $3 \times 10^{-2} \mathrm{~mol} / l$ 程度以上のものでは反応 の進行につれて粉末状の白い沈即が重合管の底部にできてくるこ とで, ポリマーの共存しない系で同様のことを試みこの白色沈殿 を取り出し種々の溶媒に対する溶解性や炎色反応を試みたところ 無機物であること，拈よびカリウムの化合物であることを確認し た。ポリマーの共存する系では収量の中にこの無機物が加算され てくるので微量分析の際に灰分として無機物の量を定量し収量か ら差し引いた。図5はこ5して求めたポリマー収量をるとにして 画いたるのである。また重合管を開管した際にチオエーテル特有 の臭いが認められる。これらの諸事実はヨウ化カリウム，ジメチ ルスルホキシド, 液体亜硫酸の 3 成分が共存してはじめて起る現 象である。したがって次式の反応が重合管の中で起っていること になる。

$$
2 \mathrm{KI}+\left(\mathrm{CH}_{3}\right)_{2} \mathrm{SO}+\text { liq. } \mathrm{SO}_{2} \longrightarrow\left(\mathrm{CH}_{3}\right)_{2} \mathrm{~S}+\mathrm{K}_{2} \mathrm{SO}_{3}+\mathrm{I}_{2}
$$

さて，こうしてできたヨウ素がいかにしてなくなっていくか，
つまり誘導期間をもたらすョウ素が何によって破壊されていくか を考光てみると，まず考放られるのはラジカル捕捉剤としての作 用である。Bartlett ら ${ }^{10)}$ 执よびその他の研究者11,12,13) によって ヨウ素が捕捉剤として働くことは認められており，この系におい ても開始剤から生じたイソブチロニトリルラジカルを捕捉する。 捕捉されるラジカルの量はヨウ素の濃度に比例する量であるので

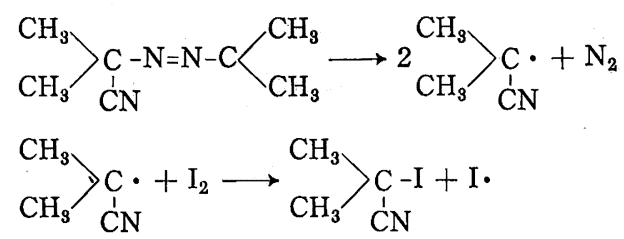

$[\mathrm{KI}]_{0}$ が大きいほど $R_{\mathrm{p}}$ が減少することになる。しかし図 6 に示 したように $R_{\mathrm{p}}$ と $[\mathrm{KI}]_{0}$ がある一定の比例関倸をもたないとこ ろを見ると，ラジカルを捕捉するものが他にも存在していること になる。後で詳しく述べる。ヨウ素の反応にジメチルスルホキシ ドとの反応がある。すなわちヨウ素で酸化されてジメチルスルホ ンになる。

$$
\mathrm{I}_{2}+\left(\mathrm{CH}_{3}\right)_{2} \mathrm{SO}+\mathrm{H}_{2} \mathrm{O} \longrightarrow\left(\mathrm{CH}_{3}\right)_{2} \mathrm{SO}_{2}+2 \mathrm{HI}
$$

反応に参加した水は液体西硫酸中に含まれている極く微量の水 であって 50〜100 ppm 存在することがカールフィッシャー法 ${ }^{14)}$ および赤外吸収スペクトル の反応が起ることはジメチルスルホキシドにヨウ素を溶かして加 熱 $\left(50^{\circ} \mathrm{C}\right)$ するとヨウ素の色が両者の濃度に依存した時間でどん ぞん消えていくこと，拉よび後述のこれらの系にスチレンと液体 亜硫酸を加えた陽イオン重合が完全に禁止されることから確認で きる。誘導期はかくして(4)，（5)両式で示したごとくヨウ糸が 完全になくなるまで続く。どちらの反応でより多くヨウ素がなく なっていくかは系に存在する AIBN と DMSO の量的関係から みても明らかなように（5）式によってである。ヨウ素とジメチ ルチオエーテルおよび無水硫酸カリウムとの反応は, 全く起らな いことも確かめた。これらは，重合を停止させる不純物として働 く。次にヨウ素がイオン分解しないかどうかが問題となる。

$$
2 \mathrm{I}_{2}=\mathrm{I}^{+}+\mathrm{I}^{-}
$$

ヨウ素によるカチオン重合は Eley ら ${ }^{16)}$ および岡村ら ${ }^{17)}$ によ る研究があり，上述の系でも当然考えられるところである。ヨウ 素-液体亜硫酸-スチレン系では温度のいかんにかかわらずポリス チレンが得られ陽イオン重合する（イオウの定性奉験よりポリス ルホンはできていない)。一方これにジメチルスルホキシドを加 えた本実験系ではヨウ素が存在していてもポリマーは全然得られ ない(重合時間 3 時間， $\left.50^{\circ} \mathrm{C}\right)$ 。このことは（3）式でョウ素がで きるにもかかわらず（5）式でそれがどんどんなくなっていくこ とによるものである。（6）式でヨウ素カチオンができたとして もジメチルスルホキシドの酸素の不対電子に捕兄られて安定化し てしまうと考兵る。これは液体亜硫酸が共存しているため陽イオ

10) P.D. Bartlett, H.Kwart, J. Am. Chem. Soc. 72, 1051 (1950).

11) G. S. Hammond et al, ibid. 77, 3244 (1955).

12) A. H. Ewald, Disc. of Faraday Soc. 22, 138 (1956).

13) M.C.Ford, W.A.Waters, J. Chem. Soc. 1951, 1851.

14）村上, 戸倉, Bull. Chem. Soc. Japan 31, 431 (1958).

15）戸倉, 松田, 白井, ibid. 35, 371 (1962).

16) D. D. Eley, J.Saunders, J. Chem. Soc. 1952, 4167

17) 岡村, 加納, 東村, Makromol. Chem. 47, 19, 35(1961). 
ンが非常に不安定になっているためで, ジメチルス ルホキシド-液体亜硫酸中で三フッ化ホウ素エーテ ルコンプレックスを触媒としスチレンを陽イオン重 合させてもポリマーは全く得られず, これはジメチ ルホルムアミドをジメチルスルホキシドに代えたと きにも類似の現象が認められ，液体亜硫酸中ででき る陽イオンが非常に不安定であるために不対電子を もつような化合物とすぐ反応して安定化するのであ ろ ${ }^{18)}$ 。この他にも, ジメチルチオェーテルの共存 下では陽イオン重合は括こらない。したがって本実 䥐系ではラジカル重合のみがおこり，スチレンポリ スルホンのみを与える。

次に $R_{\mathrm{p}}$ と $[\mathrm{KI}]_{0}$ の関係（図 6) であるが上述 のよ5な反応が重合反応以外にも拈こっていて複雑 であり，その関係を定量的に説明することは困難で ある。ジメチルチオェーテルや無水亜硫酸カリウム が重合を抑制することは事実で，重合系に投入し、て 行なうと確かに收量は低下する。しかしそれの補正 など行なって正確な関係をもとめることは困難であ る。

$3 \cdot 1 \cdot 2 \cdot 2 \quad$ アクリロニトリルの重合 [アクリロ= トリル $]_{0}=5.81 \mathrm{~mol} / l$ とした以外は $3 \cdot 1 \cdot 2 \cdot 1$ と同 じ条件下で重合を行なった。図 7, 図8 亿結果を示 す。スチレンの重合と同様の考察を行ならことがこ の場合にも妥当である。アクリロニトリルの場合に 陽イオン重合の起りえないのは，明らかなことであ る。

\section{$3 \cdot 1 \cdot 3$ 塩化リチウムを添加した場合}

$3 \cdot 1 \cdot 3 \cdot 1$ スチレンの重合 $[\text { スチレン }]_{0}, \quad[\mathrm{DM}$ $\mathrm{SO}]_{0}, \quad\left[\text { liq. } \mathrm{SO}_{2}\right]_{0}$ は 3.1・1・1 と同様の濃度で行ない $[\mathrm{ABIN}]_{0}$ は $2.32 \times 10^{-2} \mathrm{~mol} / l$ に固定した。塩化リチウム初濃度（[LiCl $]_{0} ）$ は, $5.64 \times 10^{-3} \sim 1.93 \times 10^{-1} \mathrm{~mol} / l$ の間で変化させた。重合率時間曲線を図 9 に示す。添加の影響はほとんど喼められない。

3・1・3.2 アクリロニトリルの重合この場合にも顕著な影響 を認めることはでさなかった(図10)。ジメチルホルムアミド中で アクリロニトリルを重合させ塩化リチウムを添加した Bamford ら²)の結果とあわせ考えると，著者らの場合とは溶媒が変化して いるだけで，それによって均一系重合になるのだが，他の条件は 全く同じといえる。塩化リチウムはアルカリ金属を含む結合であ るから極性溶媒の中ではイオン解離を行ない何らかの寄与を重合 反応に与えてもよさそうである。Bamford らの結果ではイオン 解離した $\mathrm{Cl}^{-}$がニトリル基の分極した $\delta^{+}$の炭素とコンプレッ クスをつくって生長連鎖末端のラジカルの極性を小さくし生長の 速度定数 $\left(k_{\mathrm{p}}\right)$ を大きくする。図 10 をみると, 混合溶媒を使っ た本実験でも速度の低下は認められるが，まず，無影響と見なせ る程度である。これは塩化りチウムが Bamford ら2)の使ったジ メチルホルムアミド中と著者らの混合溶媒中とではイオン解離す る大きさが異なるためであり，イオン解離の定性的尺度である溶

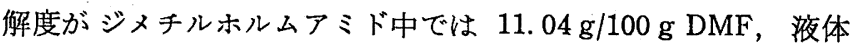
覀硫酸中では $0.01 \mathrm{~g} / 100 \mathrm{~g} \mathrm{SO} 2$ と大きく差があることからもう かがえる。臭化テトラエチルアンモニウムの液体亜硫酸中の溶解 18）戸倉, 松田, 未発表.

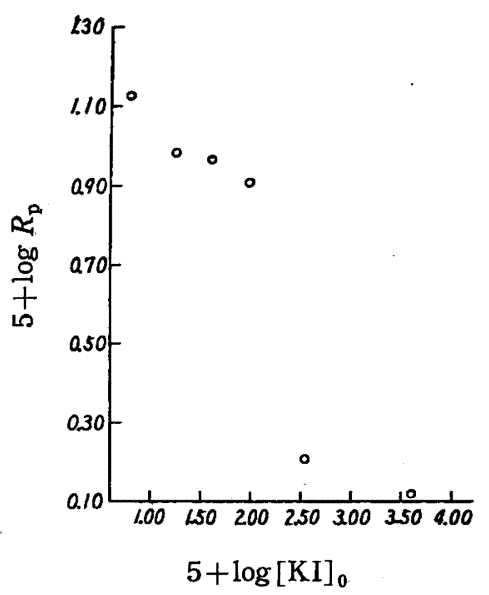

図 8 アクリロニトリルの重合 にヨウ化カリウムを添加した 時に得られた $R_{\mathrm{p}}$ と $[\mathrm{KI}]_{0}$ の両対数軸プロット

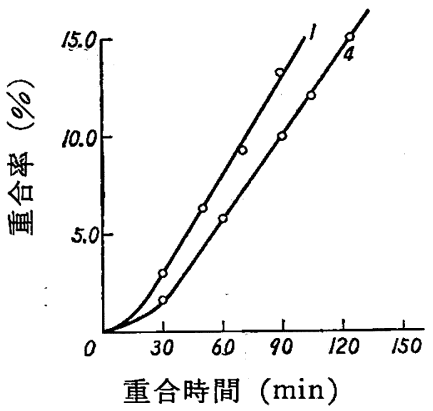

図 10 アクリロニトリルの重合 に塩化りチウムを添加した場合 の重合率一時間曲線

$1[\mathrm{LiCl}]_{0}=0^{-}$

$4 \cdot[\mathrm{LiCl}]_{0}=1.93 \times 10^{-1} \mathrm{~mol} / \mathrm{l}$
添加した場合の重合率一時間曲線

$4[\mathrm{LiCl}]_{0}=1.93 \times 10^{-1} \mathrm{~mol} / \mathrm{l}$

度はこれに比べて大きく，したがって影響を受けた。

\section{$3 \cdot 1 \cdot 4$ 臭化テトラェチルアンモニウムを添加した場合}

$3 \cdot 1 \cdot 4 \cdot 1$ スチレンの 重合 臭化テトラエチ ルアンモニウム初濃度 ([TEAB $]_{0}$ ) を $1.65 \times$ $10^{-3} \sim 7.80 \times 10^{-2} \mathrm{~mol} / \mathrm{l}$ で变化させた以外は， 3・1・1 と同じ条件で重合 を行なった。重合率一時 間の関係を図 11 に示す。 $R_{\mathrm{p}}$ の減少はほとんど認 められず初期に抑制効果 が現われる。その理由は 明らかでない。

3・1.4.2 アクリロニ

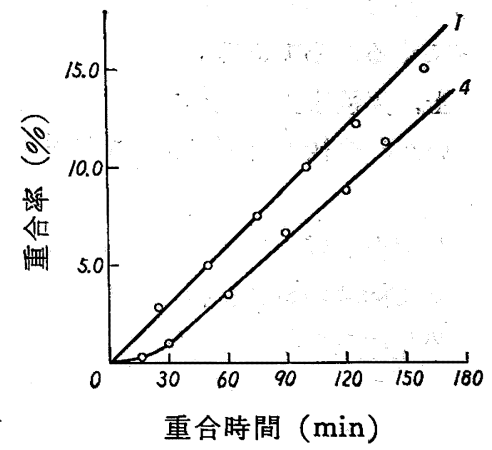

因 11 スチレンの重合に臭化テト ラェチルアンモニウムを添加し た場合の重合率一時間曲線

$1[\text { TEAB }]_{0}=0$

4 [TEAB] $_{0}=7.80 \times 10^{-2} \mathrm{~mol} / \mathrm{l}$

トリルの重合 図 12 に重合率一時間関係を, 囝 13 に $R_{\mathrm{p}}$ と, $[\mathrm{TEAB}]_{0}$ の両対数軸プロットを示す。これより $R_{\mathrm{p}}$ にたいする $[\mathrm{TEAB}]_{0}$ の関与次数を求めると -0.30 となる。すなわち, TEAB を加えていくことによって $R_{\mathrm{p}}$ は大きく减少する。Bamford $5^{2)}$ の考方方で本実験結果を考察すると， $R_{\mathrm{p}}$ が低下するの は生長連鎖末端のラジカルの極性が增大するために次のモノマー の付加を困難ならしめる。そのために生長反応の速度定数 $\left(\boldsymbol{k}_{\mathrm{p}}\right)$ 
が小さくなるという結論が出て くる。しかし, 本実験の場合に は $R_{\mathrm{p}}$ の減少はもっと複雑な要 素によって，むたらされてい ると考えられる。なぜなら， Bamford ら²) の考え方で議論 を進めると，分極したニトリル $\sim \mathrm{CH}_{2}-\dot{\mathrm{C}} \mathrm{H}$

$$
\oplus \stackrel{\mathrm{C}}{=} \underline{\underline{\mathrm{N}}} \oplus \mathrm{N}^{+}\left(\mathrm{C}_{2} \mathrm{H}_{5}\right)_{4}
$$

基の窒素の方へ混合液媒中でイ オン解離したTEABのアンモニ ウム陽イオンがやってこなけれ ばならずこのとぎは生長連 鎖末端のラジカルの極性を変化 させうるほどの効果をすたらす

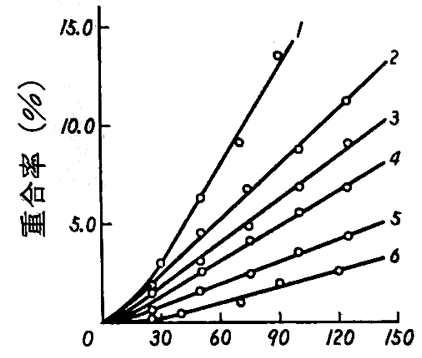

重合時間 $(\mathrm{min})$

因 12 テトラェチルアンモニ ウムブロミドを添加した時 のアクリロニトリルの重合 の重合率一時間曲線

$[\mathrm{TEAB}]_{0}=1 \quad 0$

$$
\begin{array}{ll}
2 & 1.65 \times 10^{-3} \mathrm{~mol} / l \\
3 & 4.60 \times 10^{-3} \mathrm{l} \\
4 & 1.11 \times 10^{-2} " \\
5 & 3.55 \times 10^{-2} " \\
6 & 7.80 \times 10^{-3} \mathrm{ll}
\end{array}
$$

ことは不可能である。（7）式で N-N 間に結合を考学ることは できずるちろん，イオン対として存在したときの立体的妨害に よる $R_{\mathrm{p}}$ の減少は考えられる。しかしこの立体的因子す否定され る。それはテトラェチルアンモニウム塩に拉いて $\left(\mathrm{C}_{2} \mathrm{H}_{5}\right)_{4} \mathrm{NCl}$, $\left(\mathrm{C}_{2} \mathrm{H}_{5}\right)_{4} \mathrm{NI}$ を使ったときにの関与次数は同じでないからである ${ }^{19)}$ 。

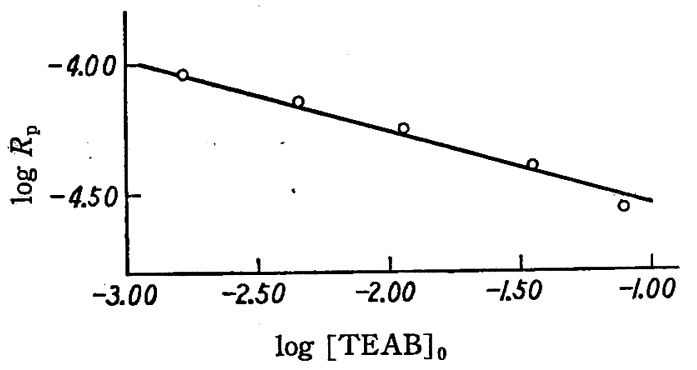

図 $13 \quad R_{\mathrm{p}}$ と $[\mathrm{TEAB}]_{0}$ の両対数軸プロット

塩類添加の影響は, Bamford らのよ5に単一な因子によって 生じる例は珍らしい。イオン解離の大きさ, 会合の現象などが加 わってくるからである。

以上, 実験事実を述べてきたが, 結論を述べる段階をで到達し えないが，今後の研究によって興味ある考察をえたいと思ってい る。

また混合溶媒のジメチルスルホキシドをジメチルホルムアミド に代えて同様の重合を行なった結果も, $[\mathrm{TEAB}]_{0}$ の -0.30 と い5関与次数を与えた（図略）。

\section{$3 \cdot 2$ 極限粘度 $([\eta])$}

ジメチルホルムアミド中, $25^{\circ} \mathrm{C}$ でウベローデ型粘度計で測定 した。ポリアクリロニトリルの場合は Houtz の式淿をを用いて分 子量を計算した。

$$
[\eta]=1.75 \times 10^{-3} M_{\mathrm{n}}^{0.66}
$$

3·2・1 ヨウ化カリウムを添加した場合 結果を表 1 , 表 2 に 示す。スチレン, アクリロニトリル両方の重合の場合とも $[\eta]$ は $[\mathrm{KI}]_{0}$ の大きい系注ど小さなる。これは亜硫酸カリウムやジメ チルチオエーテルが重合を抑制すると述べたが，この量は $[\mathrm{KI}]_{0}$ の大きい系活ど多くできてくる。イソブチロニトリルラジカルは ヨウ素によって捕捉されるから $[\mathrm{KI}]_{0}$ の大きい系汪ど連鎖生長

19）松田, Makromol. Chem. 印刷中.

20) R.C. Houtz, Textile Research J. 20, 786 (1950).
表 $1 \quad[\mathrm{KI}]_{0}$ とスチレンポリスルホンの $[\eta]$ の関係 （重合条件: $[\mathrm{AIBN}]_{0}=3.05 \times 10^{-2} \mathrm{~mol} / l, l \mathrm{liq} . \mathrm{SO}_{2}-\mathrm{DMSO}$ 混合溶媒中, $50^{\circ} \mathrm{C}$ )

$\begin{array}{ccc}{[\mathrm{KI}]_{0}(\mathrm{~mol} / \mathrm{l})} & \text { 重合染 }(\%) & {[\eta](100 \mathrm{~m} l / \mathrm{g})} \\ 3.97 \times 10^{-4} & 13.2 & 0.60 \\ 8.87 \times 10^{-4} & 13.2 & 0.58 \\ 3.39 \times 10^{-3} & 13.4 & 0.55 \\ 8.78 \times 10^{-3} & 12.0 & 0.44 \\ 3.21 \times 10^{-2} & 9.4 & 0.21\end{array}$

表 $2 \quad[\mathrm{KI}]_{0}$ とポリアクリロニトリルの $\overline{\mathrm{P}}_{\mathrm{n}}$ との関係

\begin{tabular}{ccc}
{$[\mathrm{KI}]_{0}(\mathrm{~mol} / \mathrm{l})$} & 重合象 $(\%)$ & $\bar{P}_{\mathrm{n}} \times 10^{-2}$ \\
\hline 0.0 & 32.6 & 6.4 \\
$2.57 \times 10^{-5}$ & 26.3 & 6.0 \\
$3.95 \times 10^{-4}$ & 16.9 & 4.0 \\
$4.46 \times 10^{-4}$ & 7.9 & 2.8
\end{tabular}

に働く $[\mathrm{AIBN}]_{0}$ は相対的に少なくなって $[\eta]$ を大きくしても よさそうに考えられるが，実際には $[\mathrm{AIBN}]_{0} よ り も[D M S O]_{0}$ の方がものすごく大きくヨウ素はほとんど DMSO によってつぶ されてしまい，ヨウ素と未反応の $[\mathrm{AIBN}]_{0}$ の量が $[\eta] に$ 影響を

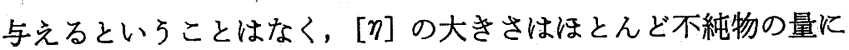
よって影響が左右されると考える。したがってヨウ化カリウムを 添加したことによる $R_{\mathrm{p}}$ や $[\eta]$ の峦化は極性の变化にもとづく ものではなく，3・1・1 にのべたような一連の反応によって生じた ものである。

$3 \cdot 2 \cdot 2$ 塩化リチウムを添加した場合 $R_{\mathrm{p}}$ にたいする影響と同

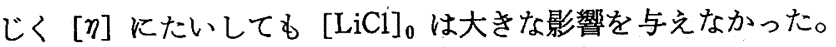
これは $\mathrm{LiCl}$ がイオン対に解離していないと考光ると説明のつく ことである。

表 $3 \cdot[\mathrm{LiCl}]_{0}$ とスチレンポリスルホンの $[\eta]$ との関係 $\left(25^{\circ} \mathrm{C}, \mathrm{DMF}\right.$ 中)

(重合条件 : $[\mathrm{AIBN}]_{0}=2.32 \times 10^{-2} \mathrm{~mol} / l$, liq. $\mathrm{SO}_{2}-\mathrm{DMSO}$ 中, $50^{\circ} \mathrm{C}$ )

\begin{tabular}{ccc}
{$[\mathrm{LiCl}]_{0}(\mathrm{~mol} / l)$} & 重合率 $(\%)$ & {$[\eta]$} \\
\hline 0.0 & 11.4 & 0.68 \\
$1.93 \times 10^{-1}$ & 13.3 & 0.53
\end{tabular}

表 $4 \quad[\mathrm{LiCl}]_{0}$ とポリアクリロニトリルの $\bar{P}_{\mathrm{n}}$ との関係

\begin{tabular}{ccc}
{$[\mathrm{LiCl}]_{0}(\mathrm{~mol} / l)$} & 重合承 $(\%)$ & $\bar{P}_{\mathrm{n}} \times 10^{-3}$ \\
\hline 0.0 & 5.8 & 4.8 \\
$1.93 \times 10^{-1}$ & 20.9 & 5.0
\end{tabular}

$3 \cdot 2 \cdot 3$ 臭化テトラエチルアンモニウムを添加した場合 スチ レンの場合には $R_{\mathrm{p}}$ と同じく余り変化していないが，アクリロニ トリルの重合では $[\mathrm{TEAB}]_{0}$ ともを大きく減少している。これ も $R_{\mathrm{p}}$ の変化と類似の傾向であって, アクリロニトリルの重合に 対してはー0.30 という関与次数を示したと同様の傾向であって， [ $\eta]$ を減少させる。 $\bar{P}_{\mathrm{n}}$ の減少は生長連鎖末端のラジカルの極性 の増大ということに結びつけて考えるのが妥当であるが，それを もたらした因子ということになると Bamford ら²)のように単一

表 $5 \quad[\mathrm{TEAB}]_{0}$ とスチレンポリスルホンの $[\eta]$ との関係（重合条件は表 3 に同じ）

\begin{tabular}{ccc}
{$[\mathrm{TEAB}]_{0}(\mathrm{~mol} / l)$} & 重合率 $(\%)$ & {$[\eta]$} \\
\hline 0.0 & 11.4 & 0.68 \\
$7.80 \times 10^{-1}$ & 11.8 & 0.53
\end{tabular}

表 $6 \quad[\mathrm{TEAB}]_{0}$ とポリアクリロニトリルの $\bar{P}_{\mathrm{n}}$ の関係

\begin{tabular}{ccc}
{$[\mathrm{TEAB}]_{0}(\mathrm{~mol} / l)$} & 重合滦 $(\%)$ & $\bar{P}_{\mathrm{n}} \times 10^{-2}$ \\
\hline 0.0 & 5.6 & 4.8 \\
$1.65 \times 10^{-3}$ & 11.3 & 4.0 \\
$4.60 \times 10^{-3}$ & 9.3 & 3.5 \\
$3.55 \times 10^{-2}$ & 3.7 & 2.3 \\
$7.80 \times 10^{-2}$ & 5.0 & 1.3
\end{tabular}


な要縈によるとは限らない。

\section{$3 \cdot 3$ ポリマー組成}

液体亜硫酸中のラジカル重合であるため, ポリマー組成に関し て考察する必要がある。

3.3.1 スチレンポリスルホン 炭水素微量分析結果を表 7 K のせる。スチレンの重合は液体亚硫酸とスチレンモノマーとが重 合が開始する前にコンプレックスをつくり，これがラジカル開始 剤の働きで重合すると説明してきている4,8)。それはポリスルホ ンの単位組成がいつも下式で表わせるようなるののポリマーであ るからであって, これは溶媒を添加しても, 重合率などを高くして も常に不変のものである。下式の単位組成をもつポリスルホンの<smiles>CCC(CC)c1ccccc1CC(C)CCOS(=O)(=O)c1ccccc1</smiles>

炭水素計算值は $\mathrm{C} \%$ が $70.59, \mathrm{H} \%$ が 5.89 である。分析試料 がポリマーであることを考虑に入れると, 塩類を添加した場合も スチレン: 二酸化イオウが $2: 1$ のポリスルホンのみを与えてい るという結果がえられる。このような規則性のある共重合物組成

\begin{tabular}{|c|c|c|c|c|}
\hline 添加物 & 澸度 $(\mathrm{mol} / \mathrm{l})$ & 重合率 (\%) & C $(\%)$ & $\mathbf{H}(\%)$ \\
\hline $\mathrm{KI}$ & 0.0 & 14.6 & 69.99 & 5.93 \\
\hline " & $8.87 \times 10^{-4}$ & 13.2 & 68.83 & 5.98 \\
\hline " & $8.78 \times 10^{-3}$ & 14.5 & 68.31 & 6.00 \\
\hline " & $3.21 \times 10^{-2}$ & 9.4 & 70.08 & 5.83 \\
\hline "I & $2.00 \times 10^{-1}$ & 3.7 & 68.98 & 5.88 \\
\hline $\mathrm{LiCl}$ & $5.64 \times 10^{-3}$ & 12.9 & 68.22 & 6.07 \\
\hline$" 1$ & $1.75 \times 10^{-2}$ & 13.4 & 67.21 & 6.03 \\
\hline " & $1.93 \times 10^{-1}$ & 13.3 & 67.19 & 6.34 \\
\hline TEAB & $1.65 \times 10^{-3}$ & 12.9 & 70.11 & 5.84 \\
\hline . & $1.11 \times 10^{-2}$ & 12.8 & 68.53 & 5.51 \\
\hline " & $7.80 \times 10^{-2}$ & 11.8 & $69 ; 38$ & 5.92 \\
\hline
\end{tabular}

を有するポリマーに対しては一般的な共重合理論よりも，コンプ レックス間の単独重合を考えた方が妥当と考える。液体亜硫酸と 分子化合物をつくるとされている ${ }^{3)}$ とろの電子供与基をるつへ ンゼン誘導体を加えた場合る，ポリマー組成が不変であっだ) いうことはコンプレックスの強固さを証明しているものである。

3.3.2 ポリアクリロニトリル 窒素分析結果を表 8 に載せる。 ポリアクリロニトリルの $\mathrm{N} \%$ 計算値は 26.42 であって, これ と比較すると一つを除いて全部低い値となっている。しかしこれ は一般認められていることで, ポリマー連鎖から HCN または $(\mathrm{CN})_{2}$ のかたちで脱離して計算值より低くなるのである。イオ ウについては定性実験からその存在はいずれす認められず，この 重合の場合も, 液体亜硫酸中のラジカル重合でありながら, ポリ アクリロニトリルのみを与えた。

\begin{tabular}{|c|c|c|c|}
\hline 添加物 & 簧度 $(\mathrm{mol} / \mathrm{l})$ & 重合事 (\%) & $\mathbf{N}(\%)$ \\
\hline KI & 0.0 & 32.6 & 25.44 \\
\hline " & $2.57 \times 10^{-5}$ & 26.3 & 26.00 \\
\hline " & $1.78 \times 10^{-4}$ & 13.1 & 24.83 \\
\hline " & $8.87 \times 10^{-4}$ & 12.4 & 25.67 \\
\hline " & 3. $39 \times 10^{-3}$ & 3.5 & 24.52 \\
\hline 11 & $8.78 \times 10^{-3}$ & 2.1 & 22.79 \\
\hline $\mathrm{LiCl}$ & $5.64 \times 10^{-3}$ & 19.9 & 25.14 \\
\hline "I & $1.75 \times 10^{-2}$ & 19.1 & 25.03 \\
\hline " & $1.93 \times 10^{-1}$ & 20.9 & 25.43 \\
\hline TEAB & $1.65 \times 10^{-3}$ & 11.3 & 26.56 \\
\hline "I & $1.11 \times 10^{-2}$ & 6.8 & 25.50 \\
\hline " & $3.55 \times 10^{-2}$ & 4.7 & 25.22 \\
\hline " & $7.80 \times 10^{-2}$ & 5.0 & 24.24 \\
\hline
\end{tabular}

(1961 年 10 月, 日本化学会東北地方大会（米沢）で発表） 液体亚硫酸の提供を受けた，製鉄化学工業株式会社に感謝しま す。

\title{
リン酸およびリン酸塩を触媒とするポリカプラミドの解重合
}

（昭和 37 年 4 月 10 日受 理）

\author{
大 谷 精 弥*
}

ポリカプラミドの解重合反応により とーカプロラクタム（以下ラクタムと略称する）を回収する方法について，主とし てダウサム $\mathrm{A}$ 熱媒体の常圧加熱による温度的 $255^{\circ} \mathrm{C}$ において新しい触媒の探求, 反応条件を検討した。この結果

（1）新しい触媒として第 1 , 第 2 , 第 3 リン酸フンモニウム，リン酸フニリンなどのリン酸塩が有効であることを見 出した。

（2）解重合速度に対する触媒の種類, 存在量の影響を調べ触媒の量が増加すると解重合速度は増加するがラクタム収 率は低下してくる傾向あること，反応の末期を除いて反応は 1 次反応であることを認めた。

（3）ポリカプラミドに対し 30〜 40\% 以上の触媒を加光解重合し，カマ(金)内に残存する触媒にポリカプラミドのみ 加え繰返し解重合すれば, 同じ触媒量でラクタム収率は $90 \%$ 以上に向上し, 反応所要時間す著しく短縮し得るこ とを見出した。この場合も反応は 1 次反応であり，触媒活性の变化を速度定数の変化で求めた。

\section{1 緒 言}

ポリカプラミドを解重合しラクタムを回収する方法については 無触媒であると解重合速度が遅いので, 種々の触媒が研究されて 打り, リン酸1,2), カセイソーダ9), カセイソーダーカセイカリ混

* 東洋レーヨン株式会社 : 東京都中央区日本橋室町.

1) P. B. Report, 44702 .
合触媒4)などの酸またはアルカリの触媒が報告され, 速度論的あ るいは機構の考察もされている。リン酸を触媒とする方法では, PB リポートによれば，加熱温度は $240 〜 300^{\circ} \mathrm{C}$ と述べられてい るが温度は高い方が解重合速度が大であり, 収率すよい傾向があ

2) R.F. Chambret, Fr. P. 992, 052 (1951).

3）渡辺, 高分子化学 9，299 (1954).

4）上田，木村，繊工試集報 25，33（1953). 